\title{
Epidemiological characteristics of imported respiratory infectious diseases in China, 2014-2018
}

Jin-Long Wang ${ }^{1 \dagger}$, Tao Chen ${ }^{1 \dagger}$, Le-Le Deng ${ }^{1}$, Ya-Jun Han ${ }^{1}$, Da-Yan Wang ${ }^{1}$, Li-Ping Wang ${ }^{2^{*}}$ and Guang-Xue He ${ }^{1^{*}}$

\begin{abstract}
Background: With the progress of globalization, international mobility increases, greatly facilitating cross-border transmission of respiratory infectious diseases (RIDs). This study aimed to analyze the epidemiological characteristics and factors influencing imported RIDs, with the goal of providing evidence to support adoption of high-tech, intelligent methods to early find imported RIDs and prevent their spread in China.

Methods: We obtained data of imported RIDs cases from 2014 to 2018 from the Inbound Sentinel Network of Customs and the National Notifiable Diseases Reporting System in China. We analyzed spatial, temporal, and population distribution characteristics of the imported RIDs. We developed an index to describe seasonality. Pearson correlation coefficients were used to examine associations between independent variables and imported cases. Data analyses and visualizations were conducted with R software.
\end{abstract}

Results: From a total of 1409265253 inbound travelers, 31732 (2.25/100 000) imported RIDs cases were reported. RIDs cases were imported from 142 countries and five continents. The incidence of imported RIDs was nearly 5 times higher in 2018 (2.81/100 000) than in 2014 (0.58/100 000). Among foreigners, incidence rates were higher among males (5.32/100 000), 0-14-year-olds (15.15/100 000), and cases originating in Oceania (11.10/100 000). The vast majority (90.3\%) of imported RIDs were influenza, with seasonality consistent with annual seasonality of influenza. The spatial distribution of imported RIDs was different between Chinese citizens and foreigners. Increases in inbound travel volume and the number of influenza cases in source countries were associated with the number of imported RIDs.

Conclusions: Our study documented importation of RIDs into China from 142 countries. Inbound travel poses a significant risks bringing important RIDs to China. It is urgent to strengthen surveillance at customs of inbound travelers and establish an intelligent surveillance and early warning system to prevent importation of RIDs to China for preventing further spread within China.

Keywords: Imported respiratory infectious disease, Influenza, Epidemiological characteristics, Associated factors, China

\footnotetext{
*Correspondence: wanglp@chinacdc.cn; hegx@chinacdc.cn

${ }^{\dagger}$ Jin-Long Wang and Tao Chen contributed equally to this work ${ }^{1}$ National Institute for Viral Disease Control and Prevention, Chinese Center for Disease Control and Prevention, Beijing, China

2 Division of Infectious Diseases, Chinese Center for Disease Control and Prevention, Beijing, China
}

\section{Background}

Globalization, increasing air travel, and greater population mobility facilitate inter-regional spread of infectious diseases, including emerging infectious diseases (EIDs) $[1,2]$. In 2018, there were 1.4 billion international trips, $10 \%$ of which involved Chinese citizens [3]. Increased population mobility leads to more rapid and higher 
volume cross-border spread of infectious diseases [1]. The 1918 influenza pandemic spread by sea and land, but its international spread was slower than cross-border spread of infectious diseases is today. Indeed, infectious diseases can traverse the globe within a single day [4-6]. More attention should be paid to surveillance, early warning, prevention, and control of cross-border spread of infectious diseases.

Since the twentieth century, EIDs, especially severe acute respiratory infectious diseases (RIDs), occur constantly and have had an enormous impact on human health and social development [2]. Rapid development of human societies, convenient transportation, and frequent international exchanges have accelerated cross-border spread of RIDs, posing significant challenges to their prevention and control. Middle East respiratory syndrome (MERS) was first reported in Saudi Arabia in 2012, and spread to other countries through travel of infectious MERS cases. As of April 26, 2016, 1728 laboratory-confirmed MERS cases had been reported in 27 countries [7]. In 2015, Guangdong Province reported their first imported MERS case-imported from the Republic of Korea-but Guangdong's rapid response and control avoided onward spread and outbreaks of MERS [8, 9].

Over recent decades, several international studies evaluated the relationship between population mobility and spread of infectious diseases [10-12]. Two studies of travel-related infections, based on long-term surveillance data analysis, described the epidemiology of imported infections [13-15]. However, detailed epidemiological characteristics and influencing factors for imported RIDs in China have not been further explored and analyzed. To fill this knowledge gap, we investigated the epidemiological characteristics and factors related to imported RIDs in China, with the goal of promoting use of high-tech methods to rapidly detect and prevent importation of key RIDs to China.

\section{Methods}

\section{Data collection and resources}

We obtained imported RIDs surveillance data and inbound traveler data, reported between January 1, 2014 and December 31, 2018, from the entry-exit sentinel network of customs (EESNC), which consists of 272 quarantine sentry points in the 31 provinces of mainland China [13], and from the National Notifiable Disease Reporting System (NNDRS) of the Chinese Center for Disease Control and Prevention (CCDC) [16]. Imported RIDs cases were classified into Chinese citizen or foreigner based on documented nationality. We obtained data on 430 imported RIDs cases from 48 countries from NNDRS, and data on 31302 imported RIDs cases from 140 countries from EESNC. Analyzed variables included gender, age, nationality, disease, time of importation, country of origin, province, entrance way, travel purpose, detection method, and main symptoms. Imported RIDs case data from the EESNC and NNDRS are routine surveillance data that were used under license for our study; all case data were anonymized.

We downloaded global influenza weekly surveillance data of 174 countries for January 1, 2014, to December 31, 2018, from FluNet (https://www.who.int/tools/flunet) [17] to analyze the correlation between the number of reported influenza cases in source countries and the number of imported cases in China analyzing with data from EESNC and NNDRS.

Statistics on gender, age, and continent of origin of foreign nationals from 25 countries and regions traveling to China each year were obtained from the China Statistical Yearbook (http://www.stats.gov.cn/english/Stati sticaldata/AnnualData) [18]. However, the incidence of imported RIDs from Chinese travelers by gender, age, and continent could not be calculated because this information was not available on inbound Chinese travelers.

\section{Data management and quality control}

Two research staff unified criteria and definitions of the data elements in the data bases. Imported RIDs information came from linkage of EESNC and NNDRS; duplicates were removed. Because influenza accounts for more than $90 \%$ of the total imported RIDs, we evaluated the relation between imported influenza RIDs and region of origin. We made a scatter plot for the continents of origin using imported influenza data and annual influenza surveillance report data from source countries.

\section{Statistical analysis}

Imported RIDs incidence per 100000 travelers was estimated as the number of imported cases divided by the number of inbound travelers during a given time period. A seasonal index of imported RIDs was calculated by dividing the number of imported respiratory infections per month by the average number of imported RIDs per year. A seasonal index greater than 1 indicates that the number of imported RIDs in a given month was higher than the monthly average. We used a radar chart of the monthly seasonal index of imported RIDs to show seasonal distribution characteristics. Continuous variables were summarized as medians and ranges, and categorical variables were summarized as numbers and percentages. Pearson correlation coefficients were used to examine associations between independent variables and imported infections. Data analysis and visualization were conducted with $\mathrm{R}$ version 4.0.5 (https://www.r-project. org/), using tidyverse, reshape2, RColorBrewer, lubridate, and basic $R$ packages. 


\section{Results}

\section{General characteristics}

From 2014 to 2018, approximately 1409.27 million passengers entered mainland China by a variety of legal routes; $87.6 \%$ of the enterers were Chinese citizens and $12.4 \%$ were foreign nationals. During these 5 years, 31732 imported RIDs cases were reported-an incidence of 2.25 RIDs cases per 100000 international travelers entering China. The imported RID incidence in $2018(2.81 / 100000)$ was nearly 5 times that in 2014 $(0.58 / 100000)$. The imported RID incidence among foreigners (4.21/100 000) was higher than among Chinese citizens (1.97/100 000). Among foreigners, the incidence was highest in males $(5.32 / 100000)$, in 0-14-yearolds (15.15/100 000), and in travelers from Oceania (11.10/100 000). The average age of the 20758 (65.4\% of RIDs) males importing RIDs was older than that of females importing RIDs [male median age: 34, interquartile range (IQR): 21-48; female median age: 28, IQR: 11-44]. Twenty-seven types of RIDs were detected, including influenza (90.3\%), rhinovirus (3.2\%), and others (6.5\%) (Tables 1, Table 2, Fig. 1).

\section{Spatial distribution}

RIDs were imported from 142 countries and five continents, mostly Asian (52.8\%), with entry along the developed coastal border areas of China. Most RIDs imported by Chinese citizens were imported from Thailand (14.1\%), the Republic of Korea (7.9\%), Japan (7.2\%), and Singapore (4.2\%). Most RIDs imported by foreign nationals were imported from the Republic of Korea (12.8\%), Japan (10.4\%), Vietnam (7.6\%), and the Philippines (5.9\%). Guangdong Province had the highest number of imported cases, followed by Jiangsu Province, and Shanghai (Figs. 1, 2).

\section{Temporal distribution}

From 2014 to 2017, the month with the most imported RIDs was July, with seasonal indices ranging from 2.79 to 9.97. In contrast, in 2018, the months with most imported RIDs were January-March (Fig. 3).

\section{Correlation analysis}

The Pearson correlation coefficient between the number of imported cases and inbound travel volume was 0.775 [95\% confidence interval (CI) 0.547 to 0.896]. A linear relationship was observed from the scatter plot, and a best-fit line was calculated using the leastsquares method. By simple linear regression, the slope of the regression line was 0.441 , implying that the average annual increase of imported RIDs cases was 0.441 per 10000 foreigners entering China. The simple linear regression model explained $58.3 \%$ of the variance (adjusted $\mathrm{R}^{2}=0.583$ ); the regression model was statistically significant, $F(1,23)=34.5, P<0.001$ (Fig. 4).

The number of imported influenza cases increased with increases of influenza reports from source countries. Importation epidemiologic characteristics varied by continent. Asian countries imported the most influenza cases to China, but the number of influenza cases reported by Asian countries was relatively low (Fig. 5).

\section{Discussion}

Respiratory infectious diseases have a huge impact on the health of people around the world. With increasing globalization, social, economic, cultural, and population exchanges across countries worldwide are increasing, and the prevention and control of RID cross-border transmission is facing significant challenges [19, 20]. We described the epidemiological characteristics of imported RIDs to China during 2014-2018, and showed that number of imported RIDs cases was positively correlated with the number of inbound travelers and the number of influenza cases in source countries. Influenza accounted for the majority of imported RIDs and showed seasonality that was consistent with influenza seasonality. The spatial distribution of imported RIDs was different between Chinese citizens and foreign nationals. Among inbound foreigners, the incidence of imported RIDs was higher in males, 0-14-year-olds, and people from Oceania. The number of imported RIDs increased with increasing inbound travel volume and increasing number of influenza cases in source countries. We believe the findings can help improve surveillance and early warning of imported RIDs, promote joint prevention and control of infectious diseases among countries with a high burden of RIDs, and protect the health and safety of people around the world.

Other researchers have found differences in the incidence of travel-related infectious diseases by gender and age group [21, 22]. The differences are related to type of infectious disease, population characteristics, and destination of travel [22]. In our study, males and 0-14 yearolds were at greater risk of importing RIDs, consistent with previous studies [23-26]. Most travelers are male and may be more susceptible to RIDs due to risk behaviors and habits during travel. Children may be more vulnerable to respiratory infections because of a lack of adequate protection from infectious diseases and lower immunity than adults [27]. Most children have been infected with at least one influenza virus by the age of six [28]. Children infected with influenza during travel will increase the risk of infection in their parents and other relatives. Influenza risk can be reduced by vaccination in advance of travel [29]. 
Table 1 Characteristics of 31732 imported respiratory infectious diseases cases in China, 2014-2018

\begin{tabular}{|c|c|c|c|}
\hline Variables & $\begin{array}{l}\text { Total cases } \\
N(\%)\end{array}$ & $\begin{array}{l}\text { Chinese } \\
N(\%)\end{array}$ & $\begin{array}{l}\text { Foreigner } \\
N(\%)\end{array}$ \\
\hline \multicolumn{4}{|l|}{ Sex } \\
\hline Male & $20758(65.4)$ & $14988(61.5)$ & $5770(78.5)$ \\
\hline Female & $10974(34.6)$ & $9392(38.5)$ & $1582(21.5)$ \\
\hline \multicolumn{4}{|l|}{ Age } \\
\hline $0 \sim$ & $7240(22.8)$ & $6307(25.9)$ & $933(12.7)$ \\
\hline $15 \sim$ & $3535(11.1)$ & $2701(11.1)$ & $834(11.3)$ \\
\hline $25 \sim$ & $12033(37.9)$ & $8687(35.6)$ & $3346(45.5)$ \\
\hline $45 \sim$ & $7360(23.2)$ & $5473(22.5)$ & $1887(25.7)$ \\
\hline $65 \sim$ & $1564(4.9)$ & $1212(5.0)$ & $352(4.8)$ \\
\hline \multicolumn{4}{|l|}{ Disease } \\
\hline Influenza & $28656(90.3)$ & 22303 (91.5) & $6353(86.4)$ \\
\hline Rhinovirus & $1005(3.2)$ & $777(3.2)$ & $228(3.1)$ \\
\hline Others $^{\mathrm{a}}$ & $2071(6.5)$ & $1300(5.3)$ & $771(10.5)$ \\
\hline \multicolumn{4}{|l|}{ Year } \\
\hline 2014 & $1440(4.5)$ & $994(4.1)$ & $446(6.1)$ \\
\hline 2015 & $3148(9.9)$ & $2123(8.7)$ & $1025(13.9)$ \\
\hline 2016 & $5084(16.0)$ & $3344(13.7)$ & $1740(23.7)$ \\
\hline 2017 & $13233(41.7)$ & $10882(44.6)$ & $2351(32.0)$ \\
\hline 2018 & $8827(27.8)$ & 7037 (28.9) & $1790(24.4)$ \\
\hline \multicolumn{4}{|l|}{ Source continent } \\
\hline Africa & $262(0.8)$ & $125(0.5)$ & $137(1.9)$ \\
\hline Americas & $1091(3.4)$ & $477(2.0)$ & $614(8.4)$ \\
\hline Asia & $16749(52.8)$ & 11915 (48.9) & $4834(65.8)$ \\
\hline Europe & $1528(4.8)$ & $834(3.4)$ & $694(9.4)$ \\
\hline Oceania & $989(3.1)$ & $521(2.1)$ & $468(6.4)$ \\
\hline Unknown & $11113(35.0)$ & $10508(43.1)$ & $605(8.2)$ \\
\hline \multicolumn{4}{|l|}{ Imported province } \\
\hline Non-border province & $3042(9.6)$ & $2592(10.6)$ & $450(6.1)$ \\
\hline Border province & $28645(90.3)$ & $21746(89.2)$ & $6899(93.8)$ \\
\hline Unknown & $45(0.1)$ & $42(0.2)$ & $3(<0.1)$ \\
\hline \multicolumn{4}{|l|}{ Entrance way } \\
\hline Air & $15251(48.1)$ & $12160(49.9)$ & $3091(42.0)$ \\
\hline Land & $9861(31.1)$ & $8961(36.8)$ & $900(12.2)$ \\
\hline Water & $6020(19.0)$ & $3029(12.4)$ & $2991(40.7)$ \\
\hline Unknown & $600(1.9)$ & $230(0.9)$ & $370(5.0)$ \\
\hline \multicolumn{4}{|l|}{ Purpose } \\
\hline Tourism & $10356(32.6)$ & $9047(37.1)$ & $1309(17.8)$ \\
\hline Business & $1834(5.8)$ & $1369(5.6)$ & $465(6.3)$ \\
\hline Labour & $1351(4.3)$ & $560(2.3)$ & $791(10.8)$ \\
\hline Studying & $293(0.9)$ & $156(0.6)$ & $137(1.9)$ \\
\hline Visiting friends or relatives & $626(2.0)$ & $310(1.3)$ & $316(4.3)$ \\
\hline Sailor & $1538(4.9)$ & $545(2.2)$ & $993(13.5)$ \\
\hline Others & $1937(6.1)$ & $1051(4.3)$ & $886(12.1)$ \\
\hline Unknown & $13797(43.5)$ & $11342(46.5)$ & $2455(33.4)$ \\
\hline \multicolumn{4}{|l|}{ Finding way } \\
\hline Fever screening & $23997(75.6)$ & $19832(81.4)$ & $4165(56.7)$ \\
\hline Medical inspection & $5246(16.5)$ & $3286(13.5)$ & $1960(26.7)$ \\
\hline Selfdeclaration & $561(1.8)$ & $419(1.7)$ & $142(1.9)$ \\
\hline
\end{tabular}

Table 1 (continued)

\begin{tabular}{|c|c|c|c|}
\hline Variables & $\begin{array}{l}\text { Total cases } \\
N(\%)\end{array}$ & $\begin{array}{l}\text { Chinese } \\
N(\%)\end{array}$ & $\begin{array}{l}\text { Foreigner } \\
N(\%)\end{array}$ \\
\hline Reported by onboard staff & $1468(4.6)$ & $743(3.1)$ & 725 (9.9) \\
\hline Others & $460(1.5)$ & $100(0.4)$ & $360(4.9)$ \\
\hline \multicolumn{4}{|l|}{ Main symptom } \\
\hline Cough & $12951(40.8)$ & $10170(41.7)$ & $2781(37.8)$ \\
\hline Fever & $7592(23.9)$ & $5226(21.4)$ & $2366(32.2)$ \\
\hline Headache & $4556(14.4)$ & $3426(14.1)$ & $1130(15.4)$ \\
\hline Chills & $3116(9.8)$ & $2210(9.1)$ & 906 (12.3) \\
\hline Facial flushing & $1836(5.8)$ & $1421(5.8)$ & 415 (5.6) \\
\hline Muscle pain & $1105(3.5)$ & $832(3.4)$ & $273(3.7)$ \\
\hline \multicolumn{4}{|c|}{$\begin{array}{l}\text { ather respiratory diseases including: Pulmonary tuberculosis, pneumococcal } \\
\text { infection, Mycoplasma pneumoniae infection, Legionnaires' disease, } \\
\text { Streptococcus infection, Chlamydia pneumoniae infection, Pertussis, } \\
\text { Pneumococcal infection, Acute nodular pharyngitis, Adenovirus infection, } \\
\text { Haemophilus influenzae infection, Respiratory syncytial virus infection, } \\
\text { Chickenpox, Human metapneumovirus infection, coronavirus infection, } \\
\text { parainfluenza virus infection, measles, mumps, bocavirus infection, rubella, } \\
\text { scarlet fever, infectious atypical pneumonia, parvovirus infection, Middle East } \\
\text { Respiratory Syndrome }\end{array}$} \\
\hline
\end{tabular}

We observed seasonal fluctuation of imported RIDs, and such seasonality may be affected by several factors-for example, international travel on holidays and seasonality of RIDs in originating areas [30]. There is more international travel during holidays. The Chinese traditional Spring Festival in January and February and summer vacation for Chinese students abroad from July to August lead to large, temporary increases in international travel that can promote cross-border spread of RIDs. Influenza accounted for the majority of imported RIDs, and the seasonality of influenza imported to China was similar to influenza seasonality in Asian source countries. RIDs import peaked in January-March 2018, which was different timing than from 2014-2017. This unusual timing may have been related to the 2018 spring influenza pandemic in northern hemisphere countries [31].

Travel volume is a key factor influencing the number of imported RIDs cases [32,33]. Passengers who contracted an infectious disease before or during travel spread the infectious diseases to another country by cross-border travel. Generally, the risk of imported infectious diseases increases with increasing passenger volume. A previous study of the cross-border transmission of H1N1 showed a significantly increased risk of importing H1N1 from countries that received more than 1400 passengers from endemic countries [34]. Travel volumes, especially air travel volume data, are often used as an important variable for estimating the risk of infectious disease importation under certain conditions [35]. It has been reported that scientific travel restrictions can effectively curb the 
Table 2 Incidence of imported respiratory infectious diseases in China, 2014-2018

\begin{tabular}{|c|c|c|c|c|c|c|c|c|c|}
\hline \multirow[t]{2}{*}{ Year } & \multicolumn{3}{|l|}{ Chinese } & \multicolumn{3}{|c|}{ Foreigner } & \multicolumn{3}{|l|}{ Total } \\
\hline & Case $(n)$ & Passenger $(N)$ & $\begin{array}{l}\text { Incidence } \\
(1 / 100000)\end{array}$ & Case $(n)$ & Passenger $(N)$ & $\begin{array}{l}\text { Incidence } \\
(1 / 100000)\end{array}$ & Case $(n)$ & Passenger $(N)$ & $\begin{array}{l}\text { Incidence } \\
(1 / 100000)\end{array}$ \\
\hline 2014 & 994 & 222879100 & 0.45 & 446 & 26360800 & 1.69 & 1440 & 249239900 & 0.58 \\
\hline 2015 & 2123 & 242972187 & 0.87 & 1025 & 25985400 & 3.94 & 3148 & 268957587 & 1.17 \\
\hline 2016 & 3344 & 251216040 & 1.33 & 1740 & 31483700 & 5.53 & 5084 & 282699740 & 1.80 \\
\hline 2017 & 10882 & 250888523 & 4.34 & 2351 & 42943000 & 5.47 & 13233 & 293831523 & 4.50 \\
\hline 2018 & 7037 & 266585503 & 2.64 & 1790 & 47951000 & 3.73 & 8827 & 314536503 & 2.81 \\
\hline Total & 24380 & 1234541353 & 1.97 & 7352 & 174723900 & 4.21 & 31732 & 1409265253 & 2.25 \\
\hline
\end{tabular}
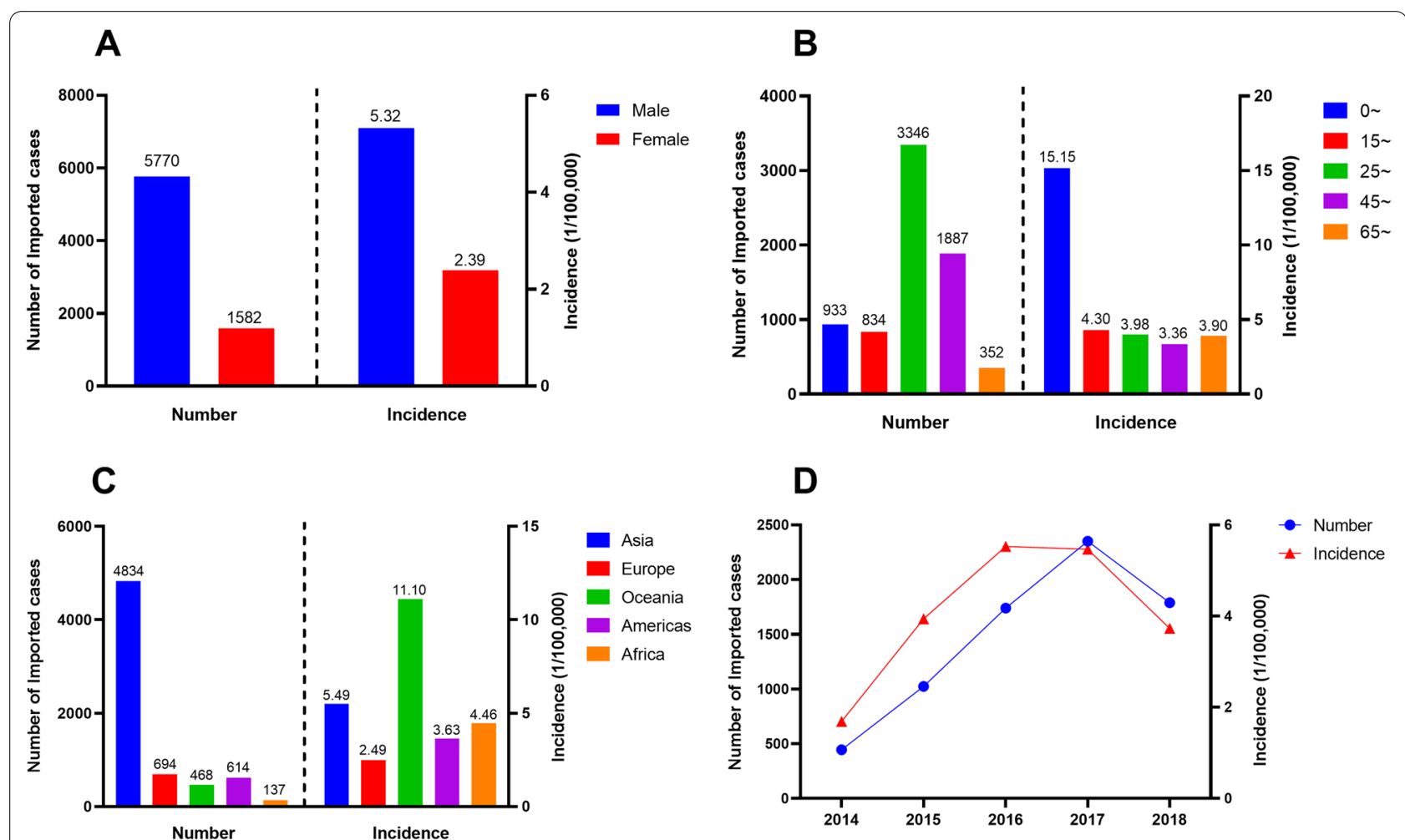

Fig. 1 The number and incidence of imported respiratory infectious diseases among inbound foreigners by $\mathbf{A}$ gender, $\mathbf{B}$ age group, C continent, and $\mathbf{D}$ year

transboundary spread of infectious diseases in the emerging and reemerging infectious diseases outbreaks-a phenomenon that has been confirmed by the practice of combating infectious diseases in recent years [36-39].

The number of imported cases is associated with the number of reported cases in source countries, which is likely related to the prevalence of the disease and population of the source country [40]. In general, the higher the prevalence of infectious diseases in a source country, the higher risk of importation into neighboring countries. However, to assess risk of importing cases, a comprehensive analysis of the prevalence of RIDs in the importing countries is required, taking into account factors such as travel restrictions, cultural practices, social environment, distance traveled, transportation, and purpose of travel. We found that the average number of reported influenza cases in Asian countries of origin was lower than those in the Americas and Europe, but Asia had the highest number of imported cases. Travel volume variables can explain some of the variation, but some 


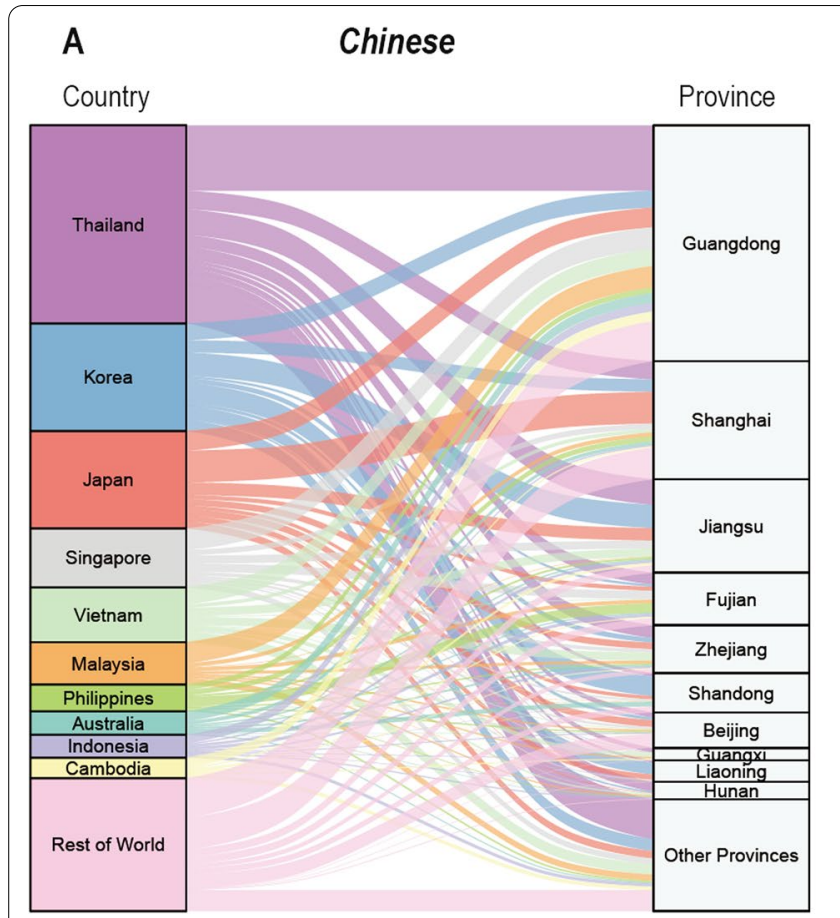

B

Country

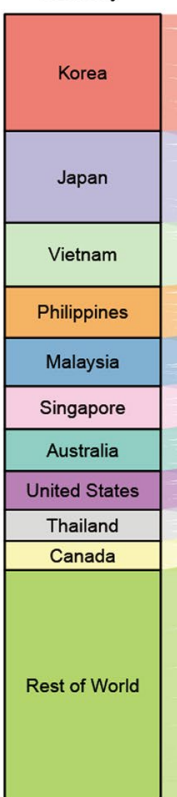

(A) Chinese and (B)

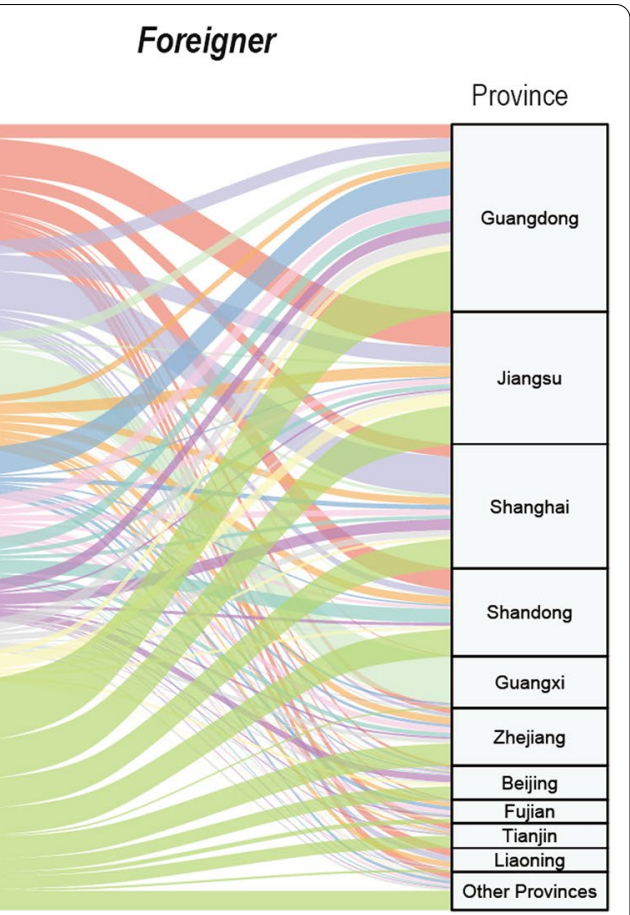

B) foreigners

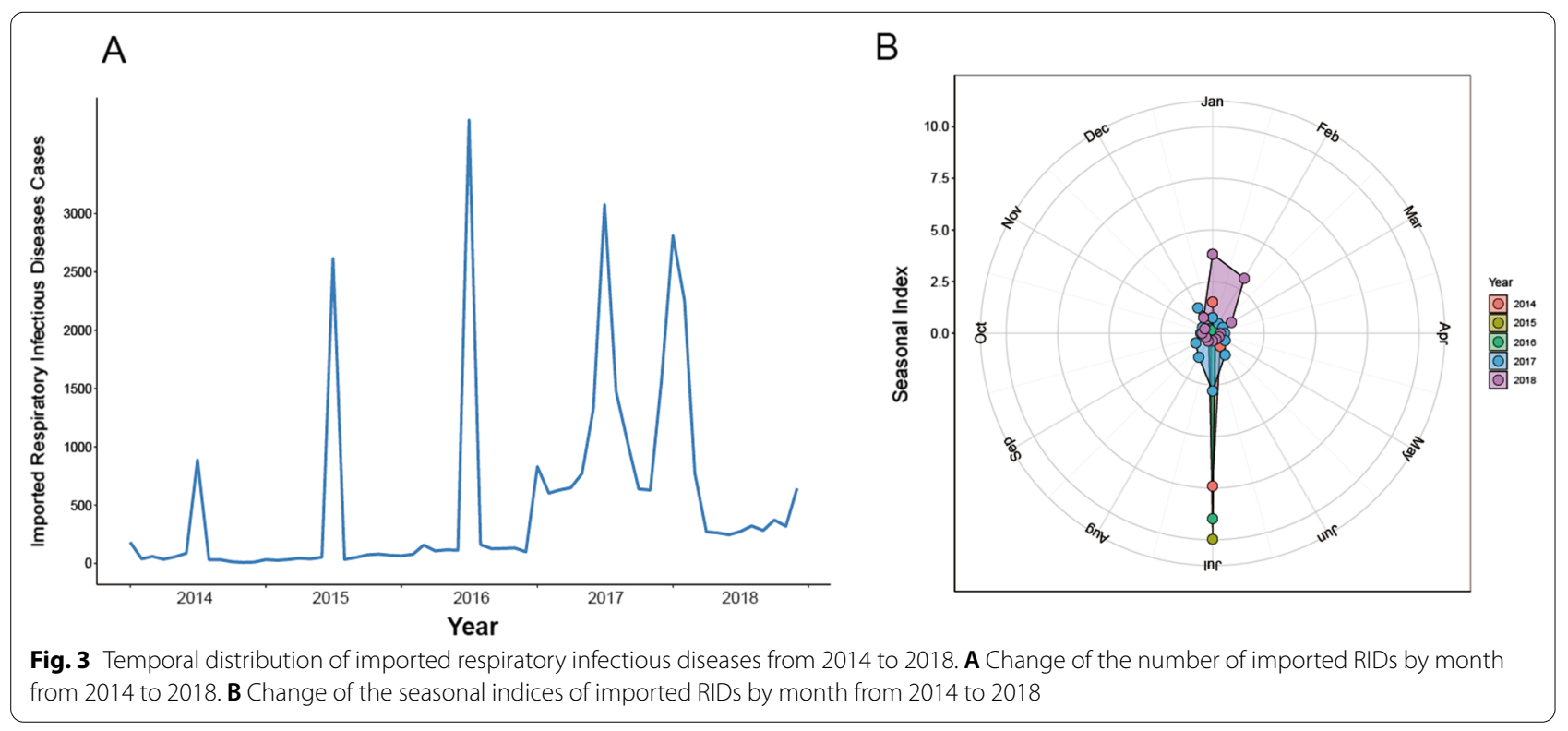

factors affecting the importation of infectious diseases require further study.

In order to assess and predict the risk of importation, investigators have developed statistical models based on data related to importation, such as international flights information, the epidemiology of selected diseases, and demographic information of source countries [41, 42].
Given the preconditions of these models, it is usually assumed that all residents have the same chance of infection and that all infected people have the same chance of boarding an outbound flight. However, this assumption may be unrealistic, leading to observed differences between predicted results of a model and the actual situation. Therefore, additional factors influencing imported 


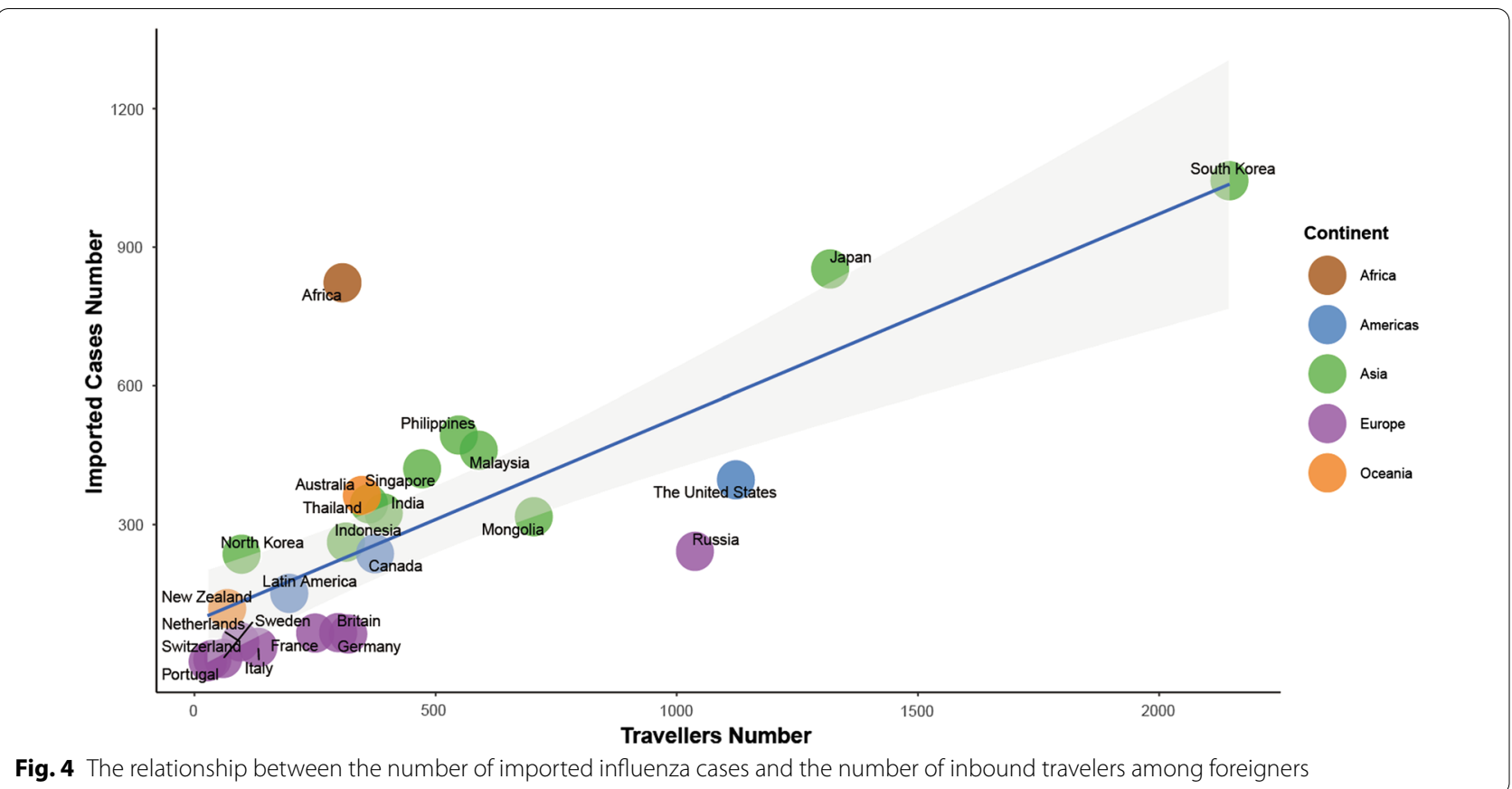

Fig. 4 The relationship between the number of imported influenza cases and the number of inbound travelers among foreigners

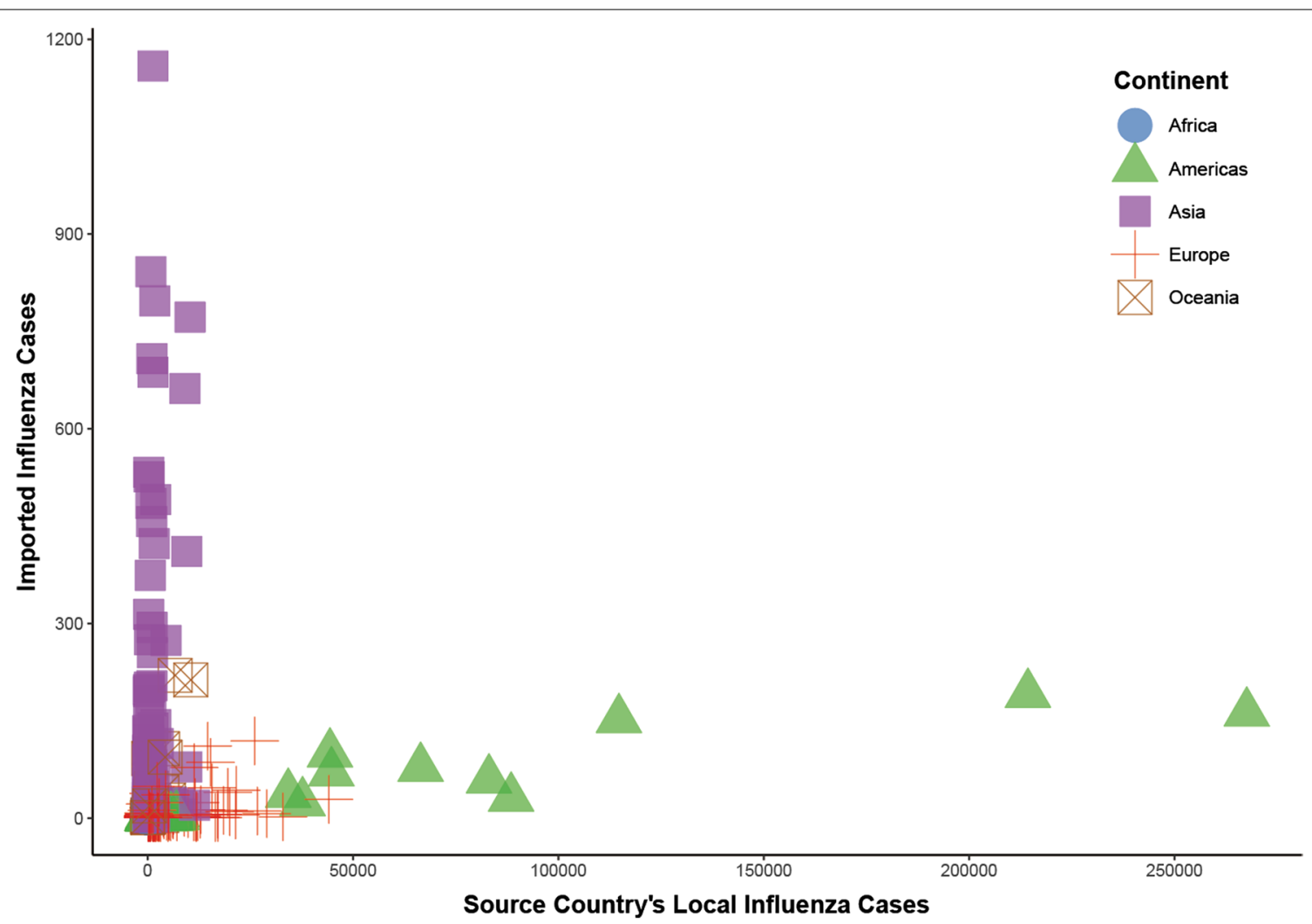

Fig. 5 Scatter plot of the number of influenza cases in the original countries and the number of imported influenza cases 
infectious diseases should be further studied and incorporated into predictive model analyses.

We believe that there are additional factors affecting the epidemiology of imported RIDs that are in need of further exploration. For example, vaccination status influences imported RIDs. Environmental changes in temperature, humidity, air pollution, and sun exposure may influence RIDs spread [43]. Travel duration is often considered as a critical factor of imported RIDs. Since the data used in our study were mainly from EESNC and NNIDRS, it is possible to lose some information in our study and might lead to inexactly calculated incidence of imported RIDs.

\section{Conclusions}

Imported respiratory infectious diseases incidence increased from 2014 to 2018. Gender, age, continent, inbound passenger volume, and the number of reported cases in source countries were associated with the incidence of imported RIDs. With annual increases in international travel, the potential risk of RIDs spread to China rises accordingly. Therefore, it is urgent to strengthen surveillance at customs for inbound travelers and establish an intelligent surveillance and warning system for imported RIDs to early find and prevent the RIDs from spreading to China. The health and safety of people around the world will be more effectively protected if infectious diseases are controlled in their countries of origin. It is therefore vital for the international community to support prevention and control of important RIDs for countries having limited resources.

\section{Abbreviations}

EIDs: Emerging infectious diseases; RIDs: Respiratory infectious diseases; MERS: Middle East respiratory syndrome; EESNC: Entry-exit sentinel network of customs; NNDRS: National Notifiable Disease Reporting System; CCDC: Chinese Center for Disease Control and Prevention; IQR: Interquartile range; Cl: Confidence interval.

\section{Acknowledgements}

We thank all healthcare workers and investigators at different levels and areas for their contribution to this study, especially Professor Liqun Fang for his technical support and Professor Lance Rodewald for English language editing.

\section{Authors' contributions}

J-LW and TC designed and implemented the study, managed and analyzed the data, interpreted the data, wrote, reviewed, and edited the manuscript. G-XH and L-PW designed the study, analysis, interpreted the data, wrote and edited the manuscript. D-YW convinced the idea, interpreted the data, critical review and edited the manuscript. L-LD, Y-JH provided support in data management and drafted and revised the manuscript. All authors read and approved the final manuscript.

\section{Funding}

This work was funded by the National Natural Science Foundation of China (No. 91846302) and the National Science and Technology Major Project (No. 2016ZX10004222). The funders had no role in study design, data collection, analysis, interpretation, and writing of the manuscript.

\section{Availability of data and materials}

According to the requirement of the EESNC and NNDRS, the original data can be used only by our researchers and cannot be provided to others.

\section{Declarations}

Ethics approval and consent to participate

The information in our study was from the EESNC and NNDRS, which is routine surveillance, and all case information was anonymized.

\section{Consent for publication}

All the authors have written the informed consent and agreed with the publication of this paper.

\section{Competing interests}

The authors declare that they have no conflict of interest.

Received: 26 September 2021 Accepted: 2 February 2022

Published online: 04 March 2022

\section{References}

1. Tuite AR, Bhatia D, Moineddin R, Bogoch II, Watts AG, Khan K. Global trends in air travel: implications for connectivity and resilience to infectious disease threats. J Travel Med. 2020;27(4):1-8.

2. Jones KE, Patel NG, Levy MA, Storeygard A, Balk D, Gittleman $J$, et al. Global trends in emerging infectious diseases. Nature. 2008:451(7181):990-3.

3. Central Broadcasting Network. In 2018, the number of outbound tourists of Chinese citizens was nearly 150 million. https://baijiahao.baidu.com/s? $\mathrm{id}=1625406407385093650 \& \mathrm{wfr}=$ spider\&for=pc. Accessed 22 Sept 2021.

4. Harvey K, Esposito DH, Han P, Kozarsky P, Freedman DO, Plier DA, et al. Surveillance for travel-related disease-GeoSentinel Surveillance System, United States, 1997-2011. MMWR Surveill Summ. 2013;62:1-23.

5. Short KR, Kedzierska K, van de Sandt CE. Back to the future: lessons learned from the 1918 influenza pandemic. Front Cell Infect Microbiol. 2018;8:343.

6. Paules C, Subbarao K. Influenza. Lancet. 2017;390(10095):697-708.

7. de Wit E, van Doremalen N, Falzarano D, Munster VJ. SARS and MERS: recent insights into emerging coronaviruses. Nat Rev Microbiol. 2016:14(8):523-34

8. Wu J, Yi L, Zou L, Zhong H, Liang L, Song T, et al. Imported case of MERS-CoV infection identified in China, May 2015: detection and lesson learned. Euro Surveill. 2015;20(24):1-4.

9. Hui DS, Perlman S, Zumla A. Spread of MERS to South Korea and China. Lancet Respir Med. 2015;3(7):509-10.

10. Hill DR. Health problems in a large cohort of Americans traveling to developing countries. J Travel Med. 2000;7(5):259-66.

11. Freedman DO, Weld LH, Kozarsky PE, Fisk T, Robins R, von Sonnenburg F, et al. Spectrum of disease and relation to place of exposure among ill returned travelers. N Engl J Med. 2006;354(2):119-30.

12. Leder K, Torresi J, Libman MD, Cramer JP, Castelli F, Schlagenhauf $P$, et al. GeoSentinel surveillance of illness in returned travelers, 2007-2011. Ann Intern Med. 2013;158(6):456-68.

13. Fang LQ, Sun Y, Zhao GP, Liu LJ, Jiang ZJ, Fan ZW, et al. Travel-related infections in mainland China, 2014-16: an active surveillance study. Lancet Public Health. 2018;3(8):e385-94.

14. Wang Y, Wang $X$, Liu X, Ren R, Zhou L, Li C, et al. Epidemiology of imported infectious diseases, China, 2005-2016. Emerg Infect Dis. 2018:25(1):33-41.

15. Wu Y, Liu MY, Wang JL, Zhang HY, Sun Y, Yuan Y, et al. Epidemiology of imported infectious diseases, China, 2014-18. J Travel Med. 2020;27(8):taaa211.

16. Wang L, Wang Y, Jin S, Wu Z, Chin DP, Koplan JP, et al. Emergence and control of infectious diseases in China. Lancet. 2008:372(9649):1598-605.

17. Flahault A, Dias-Ferrao V, Chaberty P, Esteves K, Valleron AJ, Lavanchy D. FluNet as a tool for global monitoring of influenza on the Web. JAMA. 1998;280(15):1330-2. 
18. National Bureau of Statistics of China. Annual data. 2021. http://www. stats.gov.cn/english/Statisticaldata/AnnualData. Accessed 26 Sept 2021.

19. Kubota Y, Shiono T, Kusumoto B, Fujinuma J. Multiple drivers of the COVID-19 spread: the roles of climate, international mobility, and regionspecific conditions. PLoS ONE. 2020;15(9):e239385.

20. Qiu J. One world, one health: combating infectious diseases in the age of globalization. Natl Sci Rev. 2017;4(3):493-9.

21. Schlagenhauf $P$, Chen LH, Wilson ME, Freedman DO, Tcheng D, Schwartz $E$, et al. Sex and gender differences in travel-associated disease. Clin Infect Dis. 2010;50(6):826-32.

22. Decraene V, Kühlmann BS, Andersson FM, Veličko I. Differences in travelrelated incidence of chlamydia by age groups, gender and destination: Sweden 2000-2013. Travel Med Infect Dis. 2018;25:42-9.

23. GBD Lower Respiratory Infections Collaborators. Estimates of the global, regional, and national morbidity, mortality, and aetiologies of lower respiratory infections in 195 countries, 1990-2016: a systematic analysis for the Global Burden of Disease Study 2016. Lancet Infect Dis. 2018;18(11):1191-210.

24. Nair H, Brooks WA, Katz M, Roca A, Berkley JA, Madhi SA, et al. Global burden of respiratory infections due to seasonal influenza in young children: a systematic review and meta-analysis. Lancet. 2011;378(9807):1917-30.

25. Nair H, Nokes DJ, Gessner BD, Dherani M, Madhi SA, Singleton RJ, et al. Global burden of acute lower respiratory infections due to respiratory syncytial virus in young children: a systematic review and meta-analysis. Lancet. 2010;375(9725):1545-55.

26. Gabriel G, Arck PC. Sex, immunity and influenza. J Infect Dis. 2014;209(Suppl 3):S93-9.

27. Fraaij PL, Heikkinen T. Seasonal influenza: the burden of disease in children. Vaccine. 2011;29(43):7524-8.

28. Bodewes R, de Mutsert G, van der Klis FR, Ventresca M, Wilks S, Smith DJ, et al. Prevalence of antibodies against seasonal influenza $A$ and $B$ viruses in children in Netherlands. Clin Vaccine Immunol. 2011;18(3):469-76.

29. Sauerbrei A, Schmidt-Ott R, Hoyer H, Wutzler P. Seroprevalence of influenza A and B in German infants and adolescents. Med Microbiol Immunol. 2009;198(2):93-101.

30. Yu T, Fu Y, Kong X, Liu X, Yan G, Wang Y. Epidemiological characteristics of imported malaria in Shandong Province, China, from 2012 to 2017. Sci Rep-UK. 2020;10(1):7568.

31. Price OH, Spirason N, Rynehart C, Brown SK, Todd A, Peck H, et al. Report on influenza viruses received and tested by the Melbourne WHO Collaborating Centre for Reference and Research on Influenza in 2018. Commun Dis Intell (2018). 2020:44:1-16.

32. Belderok SM, Rimmelzwaan GF, van den Hoek A, Sonder GJ. Effect of travel on influenza epidemiology. Emerg Infect Dis. 2013;19(6):925-31.

33. Mangili A, Vindenes T, Gendreau M. Infectious risks of air travel. Microbiol Spectr. 2015;3(5):1-10.

34. Khan K, Arino J, Hu W, Raposo P, Sears J, Calderon F, et al. Spread of a novel influenza A (H1N1) virus via global airline transportation. N Engl J Med. 2009:361(2):212-4.

35. Gilbert M, Pullano G, Pinotti F, Valdano E, Poletto C, Boëlle PY, et al. Preparedness and vulnerability of African countries against importations of COVID-19: a modelling study. Lancet. 2020;395(10227):871-7.

36. Vaidya R, Herten-Crabb A, Spencer J, Moon S, Lillywhite L. Travel restrictions and infectious disease outbreaks. J Travel Med. 2020;27(3):1-19.

37. Burns J, Movsisyan A, Stratil JM, Coenen M, Emmert-Fees KM, Geffert K, et al. Travel-related control measures to contain the COVID-19 pandemic: a rapid review. Cochrane Database Syst Rev. 2020;10:1-89.

38. Chinazzi M, Davis JT, Ajelli M, Gioannini C, Litvinova M, Merler S, et al. The effect of travel restrictions on the spread of the 2019 novel coronavirus (COVID-19) outbreak. Science. 2020;368(6489):395-400.

39. Wells CR, Sah P, Moghadas SM, Pandey A, Shoukat A, Wang Y, et al. Impact of international travel and border control measures on the global spread of the novel 2019 coronavirus outbreak. Proc Natl Acad Sci USA. 2020;117(13):7504-9.

40. Dudas G, Carvalho LM, Bedford T, Tatem AJ, Baele G, Faria NR, et al. Virus genomes reveal factors that spread and sustained the Ebola epidemic. Nature. 2017;544(7650):309-15.

41. Daon Y, Thompson RN, Obolski U. Estimating COVID-19 outbreak risk through air travel. J Travel Med. 2020;27(5):1-19.
42. ShengJie L, Jennifer M, LiPing W, Xiang R, HongLong Z, ZhongJie L, et al. Assessing potential airlines and the risk of Ebolavirus importation from west African countries into China. Chin Sci Bull. 2014;59(36):3572-80.

43. Sooryanarain H, Elankumaran S. Environmental role in influenza virus outbreaks. Annu Rev Anim Biosci. 2015;3:347-73.
Ready to submit your research? Choose BMC and benefit from:

- fast, convenient online submission

- thorough peer review by experienced researchers in your field

- rapid publication on acceptance

- support for research data, including large and complex data types

- gold Open Access which fosters wider collaboration and increased citations

- maximum visibility for your research: over 100M website views per year

At BMC, research is always in progress.

Learn more biomedcentral.com/submissions 